\title{
Reactivation of koi herpesvirus infections in common carp Cyprinus carpio
}

\author{
S. St-Hilaire ${ }^{1,2, *}$, N. Beevers ${ }^{1}$, K. Way ${ }^{1}$, R. M. Le Deuff ${ }^{1}$, P. Martin ${ }^{1}$, C. Joiner ${ }^{1}$ \\ ${ }^{1}$ CEFAS Weymouth Laboratory, Barrack Road, The Nothe, Weymouth, Dorset DT4 8UB, UK \\ ${ }^{2}$ Present address: Department of Biological Sciences, Idaho State University, Pocatello, Idaho 83209, USA
}

\begin{abstract}
Two co-habitation studies with common carp were conducted to determine whether latent infections of koi herpesvirus (KHV) exist. Fish were exposed to KHV using 2 different temperature profiles, which induced low and high initial mortality. Subsequently, certain groups of fish were co-habited with naïve fish while others were not. Koi herpesvirus was reactivated in fish from 3 of the 5 experimental tanks. Reactivation of the virus occurred regardless of the initial mortality associated with the virus or whether fish were co-habited with naïve fish. The reactivation of the virus in our experiments occurred several months after the initial exposure to KHV and appeared to be temperature dependent.
\end{abstract}

KEY WORDS: Koi herpesvirus $\cdot \mathrm{KHV} \cdot$ Latent infections $\cdot$ Reactivation $\cdot$ Common carp $\cdot$ Co-habitation

\section{INTRODUCTION}

Koi herpesvirus (KHV) is a newly recognised virus associated with mortality in common carp Cyprinus carpio carpio and koi carp Cyprinus carpio koi in the United States, Israel, South Africa, the European Union, Japan and South-East Asia (Bretzinger et al. 1999, Hedrick et al. 2000, Neukirch \& Kunz 2001, Way et al. 2001, 2004, Perelberg et al. 2003, Chien et al. 2004, Sano et al. 2004, Tu et al. 2004). This virus has also been reported in England, but it is not considered endemic. With the large number of koi carp imports to England and the high number of fish movements within the country, there is concern that this virus will become widely established. Introduction of KHV to naïve wild common carp populations has the potential to be detrimental to these populations.

It is unlikely that fish would be transferred into fisheries during a clinical outbreak of KHV as mortality can be as high as $90 \%$ (Hedrick et al. 2000, Perelberg et al. 2003); however, it is possible that fish that have previously been exposed to the virus, and have since recovered, could be moved to fisheries. If fish can become latent carriers of KHV and subsequently shed the virus, it could be problematic.
An important characteristic of herpesviruses is their ability to persist in their natural hosts, including those with natural or vaccine-induced immunity (Kucuktas \& Brady 1999). The virus remains dormant and noninfectious for long periods, but can be reactivated to become pathogenic with the host subsequently showing clinical signs (even mortality). The mechanism for reactivation of herpesviruses remains unknown; however, it is believed that the host's physiological state plays an important role (Roizman \& Pellet 2001). The reactivation of the virus may facilitate horizontal transmission from host to other susceptible animals.

Little is known about latency of KHV (Gray et al. 2002, Walster 2003). If KHV is similar to other herpesviruses, such as cyprinid herpesvirus (CHV) and channel catfish virus (CCV), as suggested by Watlzek et al. (2005), then it is likely to persist in its host. Survivors of a disease outbreak with these 2 other viruses become asymptomatic carriers with specific neutralising antibodies and can excrete virus (Hedrick et al. 1987, Gray et al. 1999, Sano et al. 1993). Gilad et al. (2003) demonstrated that fish exposed to $\mathrm{KHV}$ at $13^{\circ} \mathrm{C}$ did not succumb to disease until after the water temperature was increased to $23^{\circ} \mathrm{C}$, suggesting that under some conditions the 
virus can infect fish and remain in an inactive state until conditions are more favourable.

Exposure of carp to KHV at non-permissive temperatures (less than $17^{\circ} \mathrm{C}$ or greater than $28^{\circ} \mathrm{C}$ ) has been used in the Koi carp industry to induce immunity to the virus (Ronen et al. 2003). Data suggest that at the high end of the non-permissive temperature range, exposed fish develop specific immunity, which upon rechallenge, affords protection. However, there is much debate as to whether this strategy of inducing a 'natural immunity' produces latent infections in fish (Walster 2003), and whether these fish can subsequently transmit the virus to naïve fish.

The objectives of this study were to determine whether KHV can persist in common carp after initial virus exposure, and whether the virus can be transmitted to naïve fish by co-habitation.

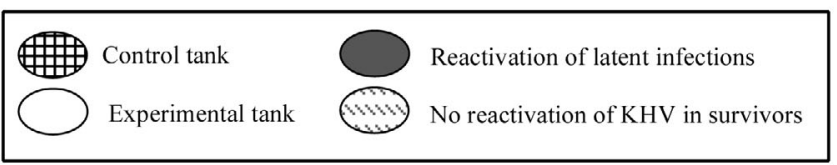

I First exposure to KHV
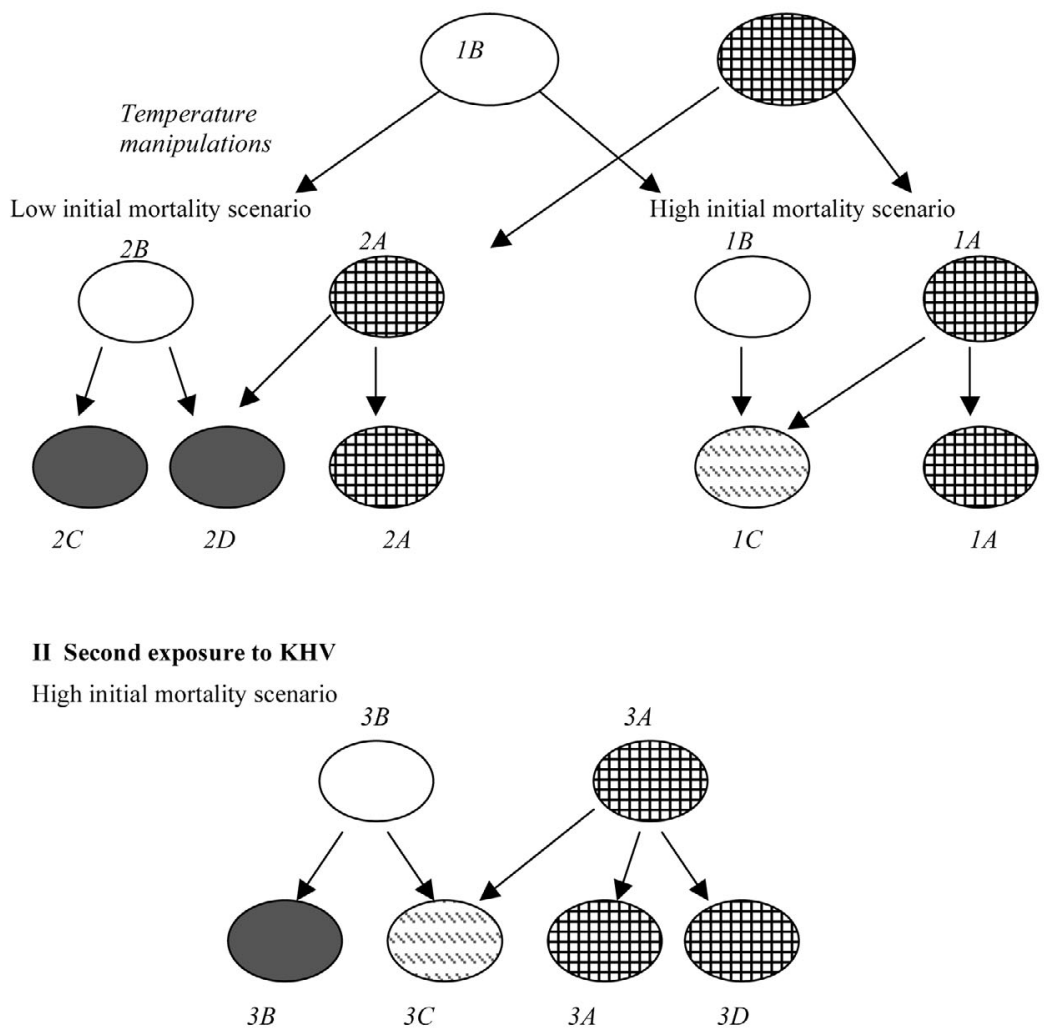

Fig. 1. Cyprinus carpio. Schematic diagram depicting the different experimental tanks used in this study. (A) First exposure to koi herpesvirus (KHV); (B) second exposure to KHV. Fish in Tank 3A were the source of the naïve fish in Tank 2D. These fish served as controls for Tank 2D during the cohabitation period $(6 \mathrm{wk})$

\section{MATERIALS AND METHODS}

Virus isolate. The UK D-132 Koi herpesvirus isolate (CEFAS) was used to challenge fish in both exposure experiments in this study. The virus was propagated on a koi fin cell line (Hedrick et al. 2000).

Fish maintenance. Fig. 1 provides a schematic diagram of the experimental tanks used in this study. All tanks, unless otherwise stated, were on a flow-through system utilizing approximately $21 \mathrm{~min}^{-1}$ of de-chlorinated bore-hole water. Fish were fed a maintenance diet of $1 \%$ bodyweight $\mathrm{d}^{-1}$ throughout the experiment. Fish were monitored for mortalities 2 times $\mathrm{d}^{-1}$ during the course of the study.

KHV Exposure 1. Fish: One thousand common carp were purchased from a private farm with no history of KHV. The fish ranged from juveniles (aged $\sim 1 \mathrm{yr}$ ), weighing between 25 and $30 \mathrm{~g}$, to older fish that weighed between 150 and $200 \mathrm{~g}$. One hundred fish were placed in each of two $300 \mathrm{l}$ tanks (Tanks 1A and 2A) and served as controls. The 800 remaining fish were placed in a 9001 tank (Tank 1B).

Prior to starting the study, fish were brought up to a temperature of $21^{\circ} \mathrm{C}$ from $10^{\circ} \mathrm{C}\left(1^{\circ} \mathrm{C} \mathrm{d}^{-1}\right.$ for $\left.11 \mathrm{~d}\right)$. Ten fish were euthanized prior to exposure to $\mathrm{KHV}$ and blood was collected from the caudal vein. Serum was tested for KHV-specific antibodies using an ELISA (see protocol below).

In vivo exposure: Fish were maintained at 2 different temperature profiles, closely resembling summer and winter water temperatures in English fisheries (see Figs. $2 \& 3$ for temperature profiles). All 800 experimental fish were exposed to approximately $10^{4}$ plaque-forming units (pfu) $\mathrm{ml}^{-1}$ of $\mathrm{KHV}$ for $2 \mathrm{~h}$ in a static bath at $21^{\circ} \mathrm{C}$. After $2 \mathrm{~h}$, flow was returned to the tank. Three hundred fish were moved to a separate $900 \mathrm{l}$ tank (Tank 2B) and the temperature was dropped to $12^{\circ} \mathrm{C}$ over a period of $4 \mathrm{~d}$. The remaining fish were left at $21^{\circ} \mathrm{C}$ for $15 \mathrm{~d}$ after which time the temperature was lowered to $12^{\circ} \mathrm{C}\left(1^{\circ} \mathrm{C} \mathrm{d}^{-1}\right)$ to ensure survivors (Tank 1B). One control tank (Tank 1A) was kept at $21^{\circ} \mathrm{C}$ for $15 \mathrm{~d}$, similar to Tank 1B while the other was dropped to $12^{\circ} \mathrm{C}$ over a $4 \mathrm{~d}$ period, similar to experimental Tank 2B. Samples of gill were taken from a sub- 


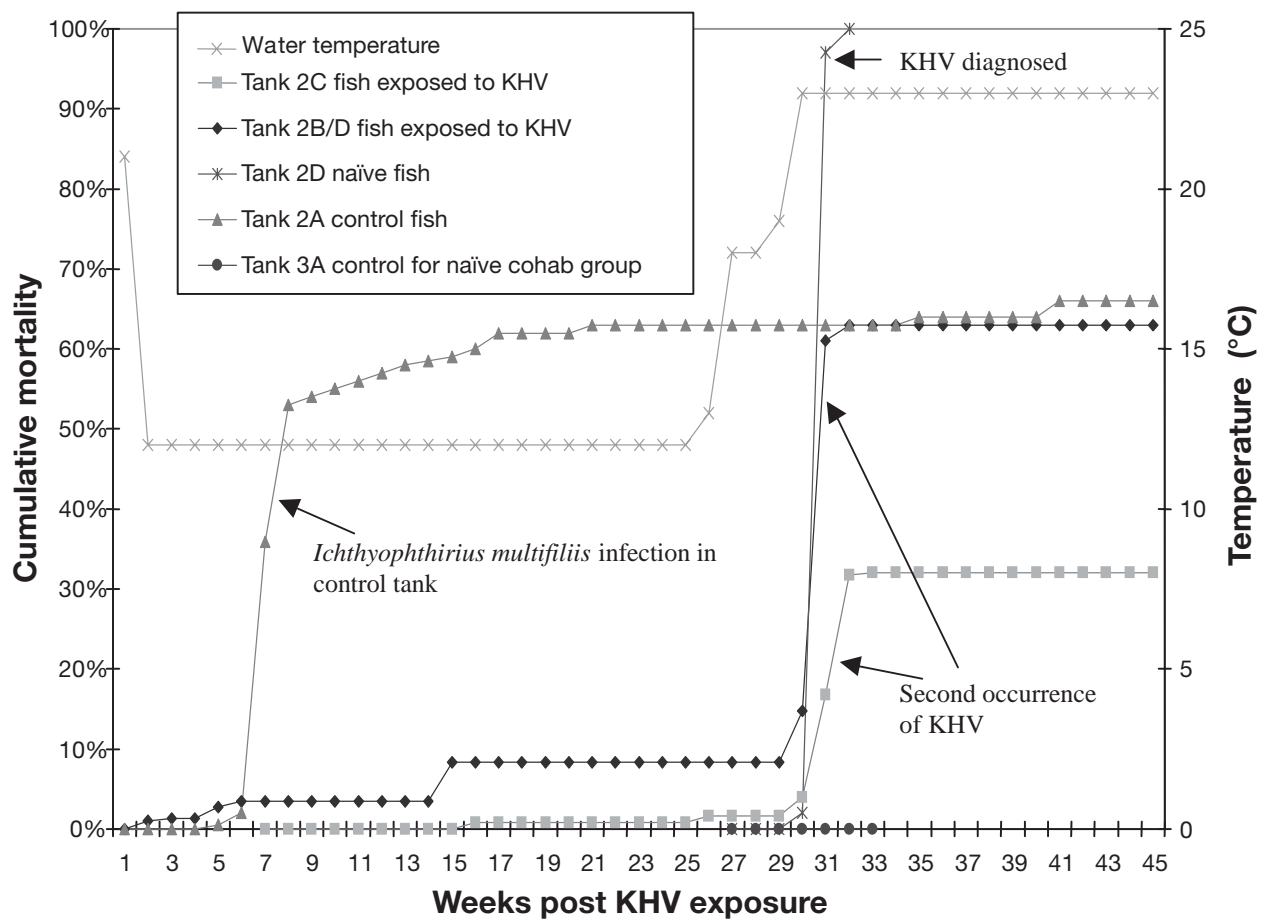

Fig. 2. Cyprinus carpio. Cumulative mortality for fish in Tanks 2A, 2B/D, 2C, 2D and 3A. Water temperature is also shown

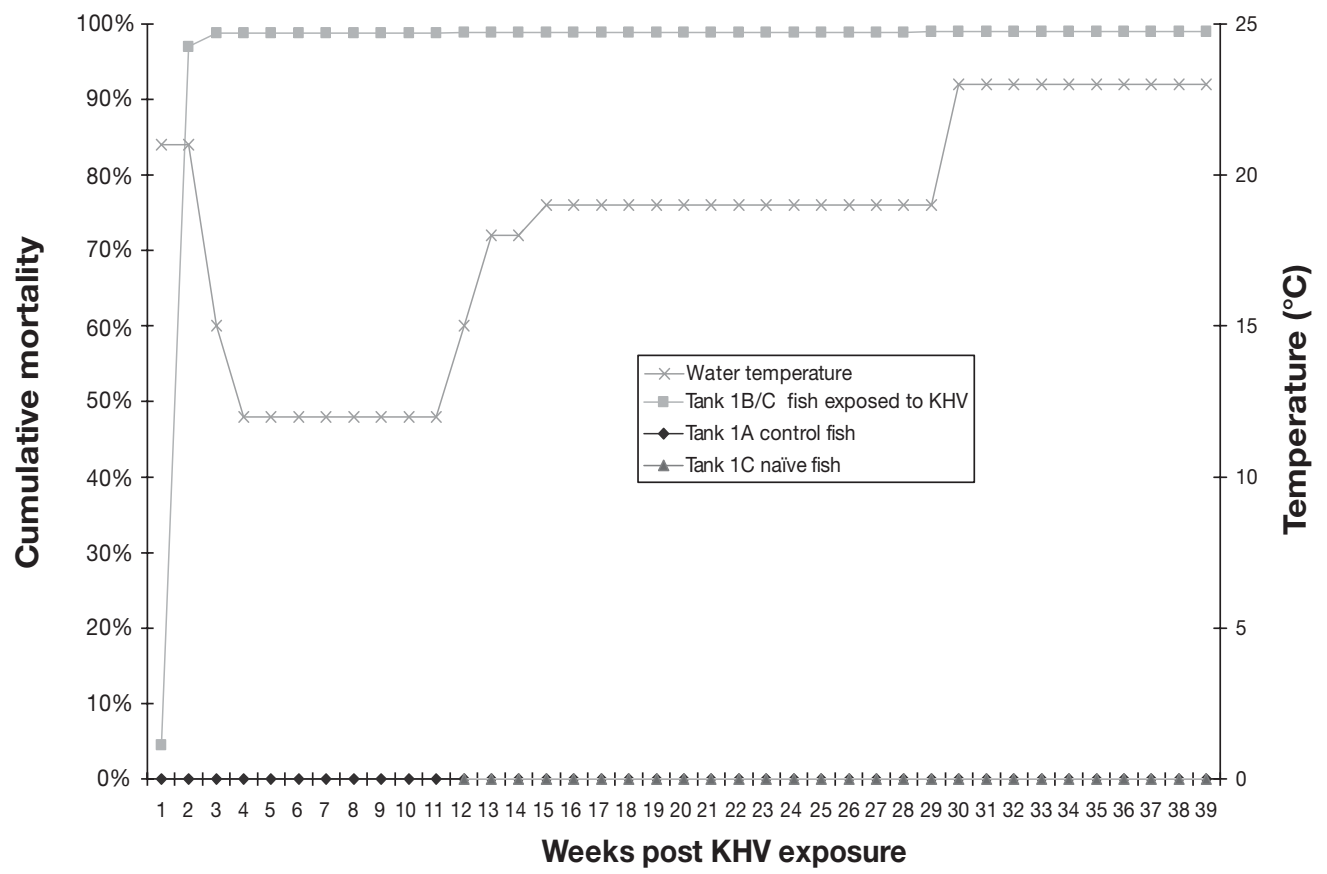

Fig. 3. Cumulative mortality for fish in Tanks $1 \mathrm{~A}$ and $1 \mathrm{~B} / \mathrm{C}$. Water temperature is also shown

sample of the fish that died, and tested by PCR to confirm KHV (see protocol below).

Samples of kidney tissue taken from 3 fish from the control tank (Tank 2A) were inoculated onto tryptone soya agar, on 2 separate occasions, to rule-out bacterial disease. Gill and skin wet mounts were examined on a regular basis during mortality events to diagnose parasite infections.

Co-habitation procedure: Low initial mortality scenario: Ten days after initial exposure to KHV the fish in Tank 2B were moved to 2 separate 3001 tanks (Tanks 2C and 2D) (150 fish tank ${ }^{-1}$ ). Tank 2C was used 
for monitoring the KHV-specific antibody response (results reported elsewhere), while Tank 2D was the source of KHV-exposed fish for this co-habitation study. The fish were held at $12^{\circ} \mathrm{C}$ for $125 \mathrm{~d}$, after which time the temperature was raised $1^{\circ} \mathrm{C} \mathrm{d}^{-1}$ over $6 \mathrm{~d}$ to $18^{\circ} \mathrm{C}$. When the tanks reached $18^{\circ} \mathrm{C}$ the co-habitation trial was initiated in Tank 2D. Fifty naïve (unexposed) fish from a stock tank were fin-clipped for identification purposes and transferred to Tank 2D. Twenty fish from the naïve stock population were tested for KHV by PCR and for KHV antibodies prior to co-habitation with the survivors. After $18 \mathrm{~d}$, the temperature was raised to $23^{\circ} \mathrm{C}\left(1^{\circ} \mathrm{C} \mathrm{d}^{-1}\right)$ (see Fig. 2 for temperature profile).

Gill tissue was collected from fish that died in Tanks 2A, 2C and 2D, 2 fish from Tank 2C and 4 fish in the co-habitation Tank 2D (2 with clipped fins and 2 without) were tested for KHV by PCR. Clinical signs were recorded for all mortalities. The experiment was terminated $135 \mathrm{~d}$ after the naïve fish were introduced to Tank 2D. At the end of the study, 10 control fish were bled and serum was tested for KHV-antibodies using an ELISA (see protocol below).

High initial mortality scenario: Fish in Tanks $1 \mathrm{~A}$ and $1 \mathrm{~B}$, which were kept at $21^{\circ} \mathrm{C}$ for $15 \mathrm{~d}$ after $\mathrm{KHV}$ exposure and subsequently maintained at $12^{\circ} \mathrm{C}$ for $59 \mathrm{~d}$, were brought back up to $19^{\circ} \mathrm{C}$ over $6 \mathrm{~d}$. Sixty-two days after exposure, approximately 2 mo after the mortality associated with KHV had subsided, the 5 initial survivors from Tank 1B were moved to a new $300 \mathrm{l}$ tank (Tank 1C). Eighty days after initial exposure, 30 naïve fish were transferred from control Tank 1A to Tank 1C that contained the KHV survivors. Prior to introducing the naïve fish to this tank, the fish were fin-clipped and 10 control fish were tested for KHV by PCR. Eightyeight days into the co-habitation study, the 5 remaining survivors in tank $1 \mathrm{C}$ were anaesthetised with benzocaine (40 $\mathrm{mg} \mathrm{l}^{-1}$; Arcos Organics) and injected with cortisol (0.2 $\mathrm{mg} \mathrm{g}^{-1}$; Sigma) intra-peritoneally. Ten control fish in Tank 1A were also injected with cortisol and fin-clipped.

After 17 wk the temperature in Tanks $1 \mathrm{~A}$ and $1 \mathrm{C}$ was increased from 18 to $23^{\circ} \mathrm{C}$ over a $5 \mathrm{~d}$ period. Fish were monitored for mortality and the experiment was terminated $194 \mathrm{~d}$ after co-habitation began, $274 \mathrm{~d}$ after the initial KHV exposure. Upon termination, blood was collected from all surviving fin-clipped fish $(\mathrm{n}=4)$ and 15 non-fin-clipped fish in Tank $1 \mathrm{C}$, as well as 14 control fish from Tank 1A. The serum of these fish was tested for KHV-specific antibodies using an ELISA.

KHV Exposure 2 (repeat of high initial mortality scenario). Fish: Six hundred common carp were purchased from a private farm with no history of KHV. The fish were juveniles (aged $\sim 1 \mathrm{yr}$ ) and weighed between 25 and $30 \mathrm{~g}$. One hundred fish were placed in a 3001 tank which served as a control (Tank 3A). The 500 remaining fish were placed in a $900 \mathrm{l}$ tank (Tank 3B). Before exposure to $\mathrm{KHV}$, fish were acclimated to a temperature of $18^{\circ} \mathrm{C}$ from $9^{\circ} \mathrm{C}\left(1^{\circ} \mathrm{C} \mathrm{d}{ }^{-1}\right.$ for $8 \mathrm{~d}$ ) and were prophylactically treated for parasites with a flush treatment of formalin at a concentration of $150 \mathrm{ppm}$. Fish were monitored for surface parasites during the course of the study, which involved lethal samples and subsequent skin and gill scrapes of fish exhibiting flashing behaviour or increased mucus production.

In vivo exposure: Prior to $\mathrm{KHV}$ exposure, 20 fish were euthanised and serum was collected for KHVspecific antibody testing. Gill tissue from these fish was sampled for KHV by PCR. Thirty of the 500 fish from Tank 3B were injected intra-peritoneally with $0.2 \mathrm{ml}$ of a viral suspension (in phosphate-buffered saline) that contained approximately 10 virus particles. Injected fish were fin-clipped and returned to the tank. These fish served as the source of virus for the remainder of the population. Of the fish that died initially, 4 were tested for KHV by PCR and virus isolation to confirm exposure. Clinical signs were recorded for all mortalities. Control fish that died during the study were tested for KHV by PCR.

Fish were exposed to $\mathrm{KHV}$ at $18^{\circ} \mathrm{C}$ and were kept at this temperature for $20 \mathrm{~d}$. After $20 \mathrm{~d}$ the fish were lowered to $16^{\circ} \mathrm{C}$ over a period of $2 \mathrm{~d}$ and were held at this temperature for $20 \mathrm{~d}$. The temperature was then lowered to $14^{\circ} \mathrm{C}$ to ensure fish survived the initial infection. The fish were held at this temperature for $20 \mathrm{~d}$ and the temperature was lowered again to $12^{\circ} \mathrm{C}_{i} 10 \mathrm{~d}$ later, the temperature was lowered to $11^{\circ} \mathrm{C}$. Fish were held at $11^{\circ} \mathrm{C}$ for $50 \mathrm{~d}$ before the co-habitation study was initiated. The control fish (Tank 3A) followed the same temperature changes as the exposed fish (see Fig. 4 for the temperature profile).

Co-habitation procedure: Twenty-nine days after the mortality associated with KHV had subsided, 78 fish were transferred from control Tank 3A into Tanks 3C and 3D (capacity 300 l) on a re-circulating system (39 fish tank $\mathrm{k}^{-1}$ ), which filtered water at approximately $21 \mathrm{~min}^{-1}$. The temperature in both re-circulation tanks was held at $11^{\circ} \mathrm{C}$. The fish in Tank $3 \mathrm{C}$ were fin-clipped (anal fin) for identification and $25 \mathrm{KHV}$ survivors from Tank 3B were introduced to the tank. The water temperature in both Tanks 3C and 3D was raised from 11 to $23^{\circ} \mathrm{C}$ at $1^{\circ} \mathrm{C} \mathrm{d}^{-1}$. A proportion of the mortalities were tested for KHV by PCR and clinical signs were recorded. The co-habitation was run for $120 \mathrm{~d}$ and terminated. At the end of the study 10 fin-clipped and non-fin-clipped fish in Tank 3C, and 10 control fish from Tank 3D, were tested for KHV-specific antibodies using an ELISA (see protocol below), and gill tissue from these fish was tested for KHV using PCR. 


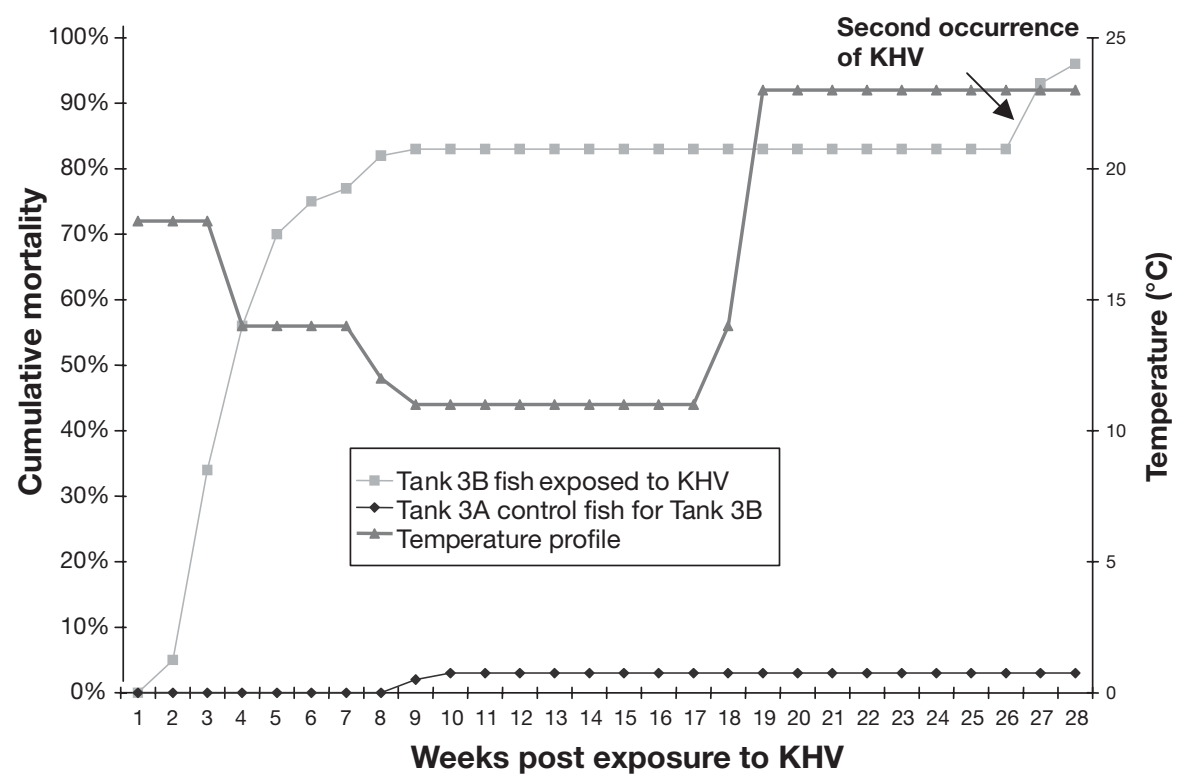

Fig. 4. Cyprinus carpio. Cumulative mortality for fish in Tanks 3A and 3B. Water temperature is also shown

The remaining fish in Tanks 3A and 3B were monitored over the same time period as the co-habitation tanks and subject to a similar increase in temperature. These fish were used to monitor the KHV-specific antibody response (results presented elsewhere). Mortalities in these tanks were also tested for KHV using PCR. At the time when the second outbreak of KHV was diagnosed in Tank 3B, 22 control fish in Tank 3A were sampled. These fish were tested for KHV using PCR. All PCR-positive tests were confirmed using DNA sequencing. Fish were also tested for KHV-specific antibodies using an ELISA (see protocol below).

Statistical analysis. Weekly cumulative mortality was calculated for each tank. When fish were sampled from the tanks the number of fish sampled was subtracted from the denominator the week they were removed. The cumulative mortality curves for tanks with the same temperature profile were illustrated on the same graph. All figures were created in Excel (Windows 2000).

DNA extraction for PCR. DNA was extracted using a standard protocol and DNAzol, (In Vitrogen, Life Technologies). Briefly, samples of gill were taken from fish and fixed in $70 \%$ ethanol. Tissue was homogenised at a $1 / 10$ dilution in transport media containing antibiotics and calf serum (Sigma). One hundred $\mu$ l of the homogenised tissue was added to a microcentrifuge tube containing $1 \mathrm{ml}$ DNAzol, reagent. The tubes were inverted 5 times at room temperature, left to stand for $5 \mathrm{~min}$, and then centrifuged at $9500 \times \mathrm{g}$ for $10 \mathrm{~min}$. One $\mathrm{ml}$ of the supernatant was transferred to another microcentrifuge tube containing $0.5 \mathrm{ml}$ of 99 to $100 \%$ ethanol. This solution was then inverted 5 times at room temperature, left to stand for $5 \mathrm{~min}$, then centrifuged for $30 \mathrm{~min}$ at $16000 \times \mathrm{g}$. The supernatant was removed and the pellet was rinsed in $1 \mathrm{ml}$ of $70 \%$ ethanol in RNase and DNase free water. After centrifuging at $16000 \times g$ for $15 \mathrm{~min}$ the ethanol was removed and the pellet was air-dried at room temperature for $5 \mathrm{~min}$ or $60^{\circ} \mathrm{C}$ for $10 \mathrm{~s}$. The pellet was then resuspended in $50 \mu \mathrm{l}$ of RNase and DNase free water and warmed to $60^{\circ} \mathrm{C}$. (The water was added, the tube vortexed and placed at $65^{\circ} \mathrm{C}$ for $5 \mathrm{~min}$, vortexed again and centrifuged for $10 \mathrm{~s}$.) Samples were extracted in duplicates and stored at $-20^{\circ} \mathrm{C}$ for PCR.

PCR amplification of KHV DNA. The detection of KHV DNA from fish tissues was done using the oligonucleotide primer set KHV9/5F and KHV9/5R published in Gilad et al. (2002).

A master mix was made containing the following: $5 \mu$ reaction buffer (×10 conc; Sigma), $2.5 \mu \mathrm{MgCl}_{2}$ (50 mM stock), $0.5 \mu \mathrm{l}$ dNTPs (25 mM of each dATP, dCTP, dGTP and dTTP; Amersham), $0.5 \mu \mathrm{l} \mathrm{KHV9/5R}$ (100 pmol $\mu^{-1}$ stock), $0.5 \mu \mathrm{KHV9/5F} \mathrm{(100} \mathrm{pmol} \mu^{-1}$

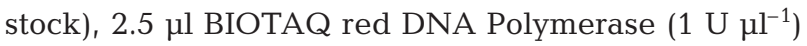
(Bioline), and $36.5 \mu \mathrm{l}$ RNase/DNase free water (BDH). A total of $47.5 \mu \mathrm{l}$ of this mastermix were overlaid with 2 drops of mineral oil (Sigma) and combined with $2.5 \mu \mathrm{l}$ of extracted DNA sample. The DNA Engine Peltier Thermal Cycler Model (Tetrad2, MJ Research) was used for amplification using 1 cycle of $94^{\circ} \mathrm{C}$ for $5 \mathrm{~min}$ followed by 40 cycles of $1 \mathrm{~min}$ at $95^{\circ} \mathrm{C}, 1 \mathrm{~min}$ at $55^{\circ} \mathrm{C}$, and $1 \mathrm{~min}$ at $72^{\circ} \mathrm{C}$, followed by 1 cycle of $10 \mathrm{~min}$ at 
$72^{\circ} \mathrm{C}$. Fifteen $\mu \mathrm{l}$ were loaded onto a $2 \%$ agarose gel for electrophoresis. The duplicate samples were run with positive and negative controls and a 100 bp ladder. The KHV product of interest was at $484 \mathrm{bp}$.

ELISA for KHV-specific antibodies. The ELISA used to detect KHV-specific antibodies was similar to that described in Crawford et al. (1999) for channel catfish virus antibodies. In brief, the wells of 96-well microtitre plates (Costar) were coated with purified KHV (UK isolate D-132) grown on koi fin cells (Hedrick et al. 2000). Virus protein was measured after purification through a sucrose gradient using the BCA Protein Assay Kit ${ }^{\mathrm{TM}}$ (Pierce) and diluted with carbonate buffer to obtain the standard concentration of $375 \mu \mathrm{g} \mathrm{ml} \mathrm{m}^{-1}$. The plate was incubated overnight for $16 \mathrm{~h}$ at $25^{\circ} \mathrm{C}$ then washed for $2 \mathrm{~min}$ (Labsystems, Wellwash Ascent ${ }^{\mathrm{TM}}$ ) with $300 \mu \mathrm{l}$ of PBS. The plates were subsequently blocked with $100 \mu \mathrm{l}$ of $10 \%$ low-fat milk powder (LFM) in PBST and incubated at $37^{\circ} \mathrm{C}$ for $1 \mathrm{~h}$. After blocking, the plates were washed for 2 min with $300 \mu \mathrm{l}$ of PBST. Fifty $\mu \mathrm{l}$ of test fish sera, diluted 1:400, $1: 800,1: 1600$ and 1:3200, was incubated onto the plates in duplicates at $37^{\circ} \mathrm{C}$ for $1 \mathrm{~h}$. Plates were washed 3 times for 2 min with $300 \mu l$ of PBST. Carp immunoglobulin (Ig) was detected by using a mouse anti-carp monoclonal antibody (Aqua Diagnostics), which recognised the heavy chain of the carp Ig molecule. The monoclonal anti-carp antibody was used at $50 \mu \mathrm{l}$ per well and incubated for $45 \mathrm{~min}$ at $37^{\circ} \mathrm{C}$. Plates were then washed, as described, after incubation of serum samples. To recognise the bound anti-carp Ig, $50 \mu \mathrm{l}$ of polyclonal rabbit anti-mouse antibody conjugated to horseradish peroxidase (enzyme) (Dako) at a dilution of 1:1000 in 10\% LFM in PBST was used at $50 \mu \mathrm{l}$ per well and incubated for $45 \mathrm{~min}$ at $37^{\circ} \mathrm{C}$. Subsequently, the plate was washed as described after incubation of serum samples. To visualise the bound rabbit antimouse antibody, the substrate for the conjugated enzyme was made by adding one phosphate-citrate sodium perborate buffer tablet (Sigma) to $100 \mathrm{ml}$ of deionised water. Two tetramethylbenzidine tablets (Sigma) were added to $20 \mathrm{ml}$ of the buffer solution and allowed to dissolve. One hundred $\mu \mathrm{l}$ of this final solution was added to each of the wells and left at room temperature for $5 \mathrm{~min}$. The reaction was subsequently stopped by the addition of $50 \mu \mathrm{l}$ per well of $\mathrm{H}_{2} \mathrm{SO}_{4}$. The absorbance was read at $450 \mathrm{~nm}$ in an Opsys MR Plate Reader ${ }^{\mathrm{TM}}$ (Dynex Technologies). One positive and one negative control were run for each plate in duplicate.

A fish was considered positive for KHV antibodies if the OD reading on the 1:1600 dilution was greater than the average for the negative control $+3 \mathrm{SD}$, and if all other lower dilutions had higher OD readings than the previous dilution.

\section{RESULTS}

\section{KHV Exposure 1}

All control fish tested before exposure to KHV were negative for KHV-specific antibodies by ELISA. None of the control fish in either control Tank 1A or 2A that died during the course of the experiment had signs consistent with $\mathrm{KHV}$, and none of the fish tested for $\mathrm{KHV}(\mathrm{n}=9$ ) were positive for the virus (using PCR). Furthermore, none of the control fish tested during the study $(\mathrm{n}=10)$ and at the end of the study $(\mathrm{n}=10)$ had antibodies to KHV.

\section{Low initial-mortality scenario}

Fish in Tank 2B, which were initially exposed to $\mathrm{KHV}$ at $21^{\circ} \mathrm{C}$ and subsequently dropped to $12^{\circ} \mathrm{C}$ experienced low mortality that began $8 \mathrm{~d}$ after exposure, and lasted $38 \mathrm{~d}$. The total mortality over this period was $3 \%$ (Fig. 2). Some of the initial mortalities had signs of KHV infection (gill and skin necrosis). One of the 10 fish that died during the initial outbreak of KHV and was tested by PCR was positive for the virus.

Fish in Tanks 2A and 2B experienced mortality associated with Ichthyophthirius multifiliis infection starting on Day 31 of the experiment (diagnosed using skin and gill wet mounts). These tanks were treated for the parasite using 2 formalin bath treatments at 100 and 200 ppm for $1 \mathrm{~h}$, administered $2 \mathrm{~d}$ apart. Tank 2A required 4 additional bath treatments with a combination of malachite green ( $1 \mathrm{ppm}$ ) and formalin at $25 \mathrm{ppm}$ for $1 \mathrm{~h}$. The 3 fish tested for KHV from Tank 2A during the disease outbreak were negative by PCR. No significant bacteriological pathogens were detected on 2 separate occasions when fish were tested for bacterial infections.

All 20 naïve fish tested prior to the start of the cohabitation trial were negative for KHV by PCR and for KHV antibodies by ELISA.

Mortality in Tank 2C (co-habitation experimental tank) began $10 \mathrm{~d}$ after the introduction of naïve fish, while the water temperature was at $20^{\circ} \mathrm{C}$. The initial survivors of KHV began to die $14 \mathrm{~d}$ after co-habitation was initiated (30 wk after the initial exposure to KHV), when the temperature was at $23^{\circ} \mathrm{C}$ (Fig. 2). Thirtythree days after the start of the co-habitation study $100 \%$ of the naïve fish and $57 \%$ of the initial survivors had died.

All mortalities in the co-habitation trial showed clinical signs of KHV infection (gill and skin necrosis). Both the initial survivors of KHV and the naïve fish tested for KHV from Tank 2D were positive for the virus by PCR. One of the 2 fish tested for KHV in Tank 2C dur- 
ing the second outbreak was positive for the virus by PCR. All 5 positive fish from this experiment were confirmed by sequence analysis. No fish died in either Tank 2A or 3A (control tank for the naïve fish introduced to Tank 2C) during the time period when the second outbreak of KHV occurred in Tanks 2C and 2D.

\section{High initial-mortality scenario}

Fish in Tank 1B experienced a $95 \%$ mortality within $19 \mathrm{~d}$ of exposure (Fig. 3). As a result, only 5 fish remained for the co-habitation trial. Twenty-nine of 34 fish tested by PCR were positive for KHV. All initial mortalities showed clinical signs consistent with KHV (gill and skin necrosis). During this period there were no mortalities in control Tank 1A.

Prior to the introduction of naïve fish from the control tank, 10 control fish were tested for KHV by PCR and declared negative. Only 2 fish died during the cohabitation period. Neither of these showed clinical signs of KHV. One fish was a survivor of the initial challenge with KHV. It was euthanised for welfare reasons after it developed a perforating ulcer from the cortisol injection. The other fish that died in Tank 1B was also negative for KHV. The naïve $(\mathrm{n}=15)$ and control ( $\mathrm{n}=14$ ) fish were all negative for KHVspecific antibodies at the end of the study. One of the 4 fish that initially survived KHV was positive for antibodies at the end of the study.

\section{KHV Exposure 2 (second high initial-mortality scenario)}

All 20 control fish tested for KHV by PCR at the start of the study were negative and none had detectable antibodies to the virus.

Mortality in Tank 3B started $11 \mathrm{~d}$ after exposure and peaked on Day 21 (Fig. 4). Mortality continued despite lowering the temperature to $16^{\circ} \mathrm{C}$ (Fig. 4). Seventythree percent of the population died and most had clinical signs consistent with KHV. Three of the 4 dead fish tested for KHV by PCR were positive for the virus. At $12^{\circ} \mathrm{C}$ there were 6 control fish that died or were euthanised for welfare reasons (skin ulcerations). These were negative for external parasites as well as for KHV by PCR.

No fish died in Tanks 3A, 3C, or 3D during the $157 \mathrm{~d}$ co-habitation trial despite the increase in temperature from 12 to $23^{\circ} \mathrm{C}$. None of the 10 fish in Tank 3D tested at the end of the study were positive for KHV by PCR or had KHV antibodies by ELISA. None of the 10 naïve or survivor fish from Tank 3C were positive for KHV by PCR, but 1 of the survivors and 1 naïve fish in Tank 3C had detectable KHV antibodies.

The fish in Tank 3B began dying $100 \mathrm{~d}$ after the initial mortality associated with KHV had subsided (25 wk after initial exposure to KHV) (Fig. 4). All fish had clinical signs consistent with KHV and 4 of the 10 fish tested by PCR were positive for the virus. KHV was confirmed by DNA sequencing. At the end of the study none of the 22 control fish in Tank 3A tested for KHV by PCR were positive for virus or for KHV-specific antibodies by ELISA $(\mathrm{n}=20)$.

\section{DISCUSSION}

The findings in this study are consistent with those of other researchers (Gilad et al. 2003, 2004) and suggest that common carp exposed to KHV can, under some circumstances, become persistently infected with the virus. Furthermore, they can shed the virus and infect naïve fish during co-habitation at temperatures above $20^{\circ} \mathrm{C}$. Given these findings, the practice of exposing fish to live virus in an attempt to immunise the fish should be used with caution, especially if these fish are to be transferred to other locations and co-habited with naïve fish. The worldwide distribution of KHV within a few years of the first isolation (Bretzinger et al. 1999, Hedrick et al. 2000, Neukirch \& Kunz 2001, Way et al. 2001, Perelberg et al. 2003, Sano et al. 2004, Tu et al. 2004) suggests that this virus may have an undetectable latent phase and, through the unregulated sale of live fish, this may have contributed to its international spread.

It is unlikely that KHV in our co-habitation tanks originated from anywhere other than the survivors of $\mathrm{KHV}$. Virus was never detected in any control tanks in any of the experiments conducted during the course of the study, and the control fish were negative for KHV antibodies at the beginning, during the course of the studies, and at the end, suggesting no exposure to the virus. Antibodies have been reported in fish exposed to KHV by Ronen et al. (2003). We also observed antibodies in the fish from our experimental tanks after the initial disease outbreak had subsided. We used an antibody response to monitor for exposure to KHV, as our cell culture and PCR techniques were not reliable at detecting the virus in sub-clinical fish. Similar findings have been reported by other researchers (Gilad et al. 2002). More recently, Gilad et al. (2004) have detected virus DNA by TaqMan PCR in fish $64 \mathrm{~d}$ postKHV exposure; however, this tool was not available at the time of this study.

It is also unlikely that KHV was reintroduced to our co-habitation tanks from an outside source, given that the water used in the studies was de-chlorinated mains water and KHV is unlikely to survive the treatment 
process. There were also no reports of KHV in other carp tanks maintained in the laboratory during the course of the studies.

Virus persistence did not appear to be a function of initial mortality associated with exposure to KHV. There was a large difference in the mortality rate between fish exposed to $\mathrm{KHV}$ at $21^{\circ} \mathrm{C}$ and maintained at that temperature and fish exposed to $\mathrm{KHV}$ at $21^{\circ} \mathrm{C}$ for a few hours but subsequently maintained at a nonpermissive temperature $\left(12^{\circ} \mathrm{C}\right.$ ) (Figs. 2, 3 \& 4). Despite this difference, persistent infections and reactivation of KHV appeared to occur in both populations.

Persistence and reactivation of KHV was not demonstrated in all tanks in this study. Only 1 (Tank 3B) of the 3 tanks (Tanks 1C, 3B, and 3C) with survivors of KHV that had a high initial mortality had a second outbreak of disease associated with the virus. In the first exposure study, where fish were maintained at a permissive temperature for $2 \mathrm{wk}$, only 5 fish survived. It seems unlikely that any of these fish remained infected with the virus, as reactivation could not be induced despite increasing the water temperature to $23^{\circ} \mathrm{C}$ and stressing fish with intra-peritoneal cortisol injections. Similarly, reactivation could not be induced in one of the tanks in the second exposure study, despite putting fish in a recirculation tank to avoid loss of virus. It seems probable that fish in Tanks $1 \mathrm{C}$ and $3 \mathrm{C}$ did not succumb to a second disease outbreak because none of the fish were persistently infected with the virus. As with many other viruses, it is likely that only a low percentage of fish within a population remain infected with KHV after the initial exposure.

Both tanks with survivors of KHV that had experienced low initial mortality when exposed to the virus had a second outbreak of disease several months after the first small outbreak had subsided (approximately $200 \mathrm{~d}$ after the initial exposure). One of these (Tank 2C) had disease associated with KHV without having naïve fish introduced to the tank, indicating that a susceptible population was not necessary for a second disease outbreak to occur. The second outbreak in Tank 3B provides further evidence that cohabitation with susceptible fish is not necessary for reactivation and propagation of the virus.

Similar to the findings of Gilad et al. (2003), temperature appeared to be a key factor in the reactivation of KHV in this study. In all tanks, the second disease outbreak coincided with a rise in water temperature above the reported permissive temperature for KHV. No other event preceded the reactivation of KHV infection. The temperature range used in this study is similar to that observed in fisheries in the UK, and might explain the apparent increase in KHV cases in the summer months. It is unlikely that a mortality rate of $3 \%$, as was observed at $12^{\circ} \mathrm{C}$, would be detected in a large fishery, so exposure to KHV could potentially go undetected until there is an increase in the water temperature. In Israel, mortality events have been reported to increase with regularity when the temperatures reach between 22 and $26^{\circ} \mathrm{C}$ in spring and autumn (Perelberg et al. 2003).

The findings of this study indicate that reactivation of KHV can occur in fish populations that have never experienced elevated mortality associated with the virus, and that it may occur long after initial exposure to the virus (up to $30 \mathrm{wk}$ ). As some fish exposed to KHV appear to become persistently infected with the virus and, under some circumstances, can shed virus again, controlling the spread of KHV requires identification of fish populations that have been exposed to the virus. Detecting these populations may be problematic with the current tools available (Gilad et al. 2002). Future research should focus on methods to identify these populations. Preliminary data from this study suggests antibodies to the virus may be useful for identifying groups of fish that have been exposed to KHV.

Acknowledgements. This work was funded by Defra (Contracts FC1150, FC1136 and FA 001) and the English Heritage Carp Organization (ECHO). We thank W. Chalmers for his editorial comments.

\section{LITERATURE CITED}

Bretzinger A, Fischer-Scherl T, Oumouna M, Hoffmann R, Truyen U (1999) Mass mortalities in koi carp, Cyprinus carpio, associated with gill and skin disease. Bull Eur Assoc Fish Pathol 19(5):182-199

Chien T, Ming Chia W, Jong-Rong S, Shih-Yuh L (2004) Detection of koi herpesvirus in Cyprinus carpio in Taiwan. Jpn Soc Fish Pathol 39:109-110

Crawford SA, Gardner IA, Hedrick RP (1999) An enzyme linked immunosorbent assay (ELISA) for the detection of channel catfish virus (CCV) in channel catfish. J Aquat Anim Health 11:148-153

Gilad O, Yun S, Andree $\mathrm{K}$, Adkinson MA, Zoltkin A, Bercovier H, Eldar A, Hedrick RP (2002) Initial characteristics of a herpesvirus and initial development of a polymerase chain reaction assay to detect the virus in koi, Cyprinus carpio koi. Dis Aquat Org 48:101-108

Gilad O, Yun S, Adkison MA, Way K, Willits NH, Bercovier H, Hedrick RP (2003) Molecular comparison of isolates of an emerging fish pathogen, koi herpesvirus, and the effect of water temperature on mortality of experimentally infected koi. J Gen Virol 84:2661-2668

Gilad O, Yun S, Zagmutt-Vergara FJ, Leutenegger CM, Bercovier H, Hedrick RP (2004) Concentrations of a koi herpesvirus (KHV) in tissues of experimentally-infected Cyprinus carpio koi as assessed by real-time TaqMan PCR. Dis Aquat Org 60:179-187

Gray WL, Williams RJ, Jordan RL, Griffin BR (1999) Detection of channel catfish virus DNA in latently infected catfish. J Gen Virol 80:1817-1822

Gray WL, Mullis L, La Patra SE, Groff JM, Goodwin A (2002) Detection of koi herpesvirus DNA in tissues of infected fish. J Fish Dis 25:171-178 
Hedrick RP, Groff JM, McDowell T, Wingfield WH (1987) Response of adult channel catfish to waterbourne exposure to channel catfish virus. Prog Fish-Cult 49:181-187

Hedrick RP, Gilad O, Yun S, Spangenberg JV (2000) A herpesvirus associated with mass mortality of juvenile and adult koi, a strain of common carp. J Aquat Anim Health 12:44-57

Kucuktas H, Brady YL (1999) Molecular biology of channel catfish virus. Aquaculture 172:147-161

Neukirch M, Kunz U (2001) Isolation and preliminary charcterization of several viruses from koi (Cyprinus carpio) suffering gill necrosis and mortality. Bull Eur Assoc Fish Pathol 21(4):125-135

Perelberg A, Smirnov M, Hutoran M, Diamant A, Bejerano Y, Kotler M (2003) Epidemiological description of a new viral disease afflicting cultured Cyprinus carpio in Israel. Isr J Aquac Bamidgeh 55(1):5-12

Roizman B, Pellet PE (2001) The family Herpesviridae: a brief introduction. In: Knipe DM, Howley PM (Eds In Chief), Griffin DE, Lamb RA, Martin MA, Roizman B, Straus SE (Assoc Eds) Fields virology. Lippincott Williams \& Wilkins, Philadelphia, PA, Vol 2, 4th edn, p 2387-2397

Ronen A, Perelberg A, Abramowitz J, Hutoran M, Tinnman S, Berjerano I, Steinitz M, Kotler M (2003) Efficient vaccine against the virus causing lethal disease in cultured Cyprinus carpio. Vaccine 21:4677-4684

Editorial responsibility: Jo-Ann Leong, Kaneohe, Hawaii, USA
Sano M, Ito T, Kurita J, Yanai T, Watanabe N, Miwa S, Iida T (2004) First detection of koi herpesvirus in cultured common carp Cyprinus carpio in Japan. Fish Pathol 39(3): 165-167

Sano N, Moriwake M, Hondo R, Sano T (1993) Herpesvirus cyprinid: a search for viral genome in infected fish by in situ hybridization. J Fish Dis 16:495-499

Tu C, Weng MC, Shiau JR, Lin SY (2004) Detection of Koi Herpesvirus in koi Cyprinus carpio in Taiwan. Fish Pathol 39(2):109-110

Walster C (2003) A note on koi herpesvirus (KHV): current situation and issues arising. Fish Vet J 7:77-81

Waltzek TB, Kelley GO, Stone DM, Way K and 6 others (2005) Koi herpesvirus (KHV) represents a third cyprinid herpesvirus (CyHV-3) in the family Herpesviridae. J Gen Virol 86:1659-1667

Way K, Le Deuff RM, Ecclestone L, Feist SW, Dixon PF, Wildgoose WH, Hedrick RP (2001) Isolation of a herpesvirus during disease outbreaks in adult koi carp, Cyprinus carpio, in the UK. Abstract from 10th Int Conf Eur Assoc Fish Pathol

Way K, Beevers ND, Joiner CL, Longshaw CB, St-Hilaire S, Stone DM, Denham KL, Dixon PF (2004) Koi herpesvirus in the UK: Detection in archive tissue samples and spread of the virus to wild carp. Abstract from 6th Int Symp Viruses Lower Vertebr, Hakodate

Submitted: March, 2005; Accepted: July 8, 2005

Proofs received from author(s): October 31, 2005 